\title{
Occurrence and molecular analysis of quarantine virus in lily cultivation areas in Brazil
}

\author{
Eliana Borges Rivas( ${ }^{(1)}$, Estevão Cardoso de Almeida Bôdi(2), Ricardo Harakava( ${ }^{(3)}$, \\ Fabio Gregori ${ }^{(4)}$ and Marcos Cesar Gonçalves ${ }^{(3)}$
}

\begin{abstract}
(1)Instituto Biológico (IB), Centro de Pesquisa e Desenvolvimento de Sanidade Vegetal (CPDSV), Laboratório de Diagnóstico Fitopatológico, Avenida Conselheiro Rodrigues Alves, № 1.252, CEP 04014-002 São Paulo, SP, Brazil. E-mail: rivas@biologico.sp.gov.br (2)Rua Esteves Júnior, no 545, CEP 88015-130 Florianópolis, SC, Brazil. E-mail: estebodi@gmail.com (3)|B, CPDSV, Laboratório de Bioquímica Fitopatológica, CEP 04014-002 São Paulo, SP, Brazil. E-mail: harakava@biologico.sp.gov.br, mcgon@biologico.sp.gov.br (4)Universidade de São Paulo, Faculdade de Medicina Veterinária e Zootecnia, Laboratório de Biologia Molecular Aplicada e Sorologia, Avenida Professor Dr. Orlando Marques de Paiva, no 87, CEP 05508-270 São Paulo, SP, Brazil. E-mail: acme@usp.br
\end{abstract}

Abstract - The objective of this work was to describe the occurrence of quarantine Tulip breaking virus (TBV, synonym Lily mottle virus - LMoV) and Lily symptomless virus (LSV), and their respective molecular analyses, to provide data for supporting TBV removal from the Brazilian A1 quarantine pest list, since this virus has spread among the main commercial lily crops in Brazil. The occurrence of these viruses was detected in 12 cultivation areas through multiplex reverse transcription (RT-PCR), using specific primers to genes encoding the respective coat proteins (CP). Eight fragments of 800 nucleotides (nt) obtained from the LMoV-infected lilies and nine fragments of $600 \mathrm{nt}$ from LSV-infected lilies were sequenced. Phylogenetic tree reconstruction showed a robust branch containing the LMoV Brazilian sequences, other LMoV isolates, TBV, and Tulip band breaking virus, suggesting that all are $\mathrm{LMoV}$ isolates, although they are clustered into two subgroups. Phylogenetic analysis also showed a robust branch supporting all Brazilian and other LSV sequences, except for an LSV Japanese isolate. Recombination analyses also showed an LMoV recombinant isolate, whereas no recombination events were found among LSV isolates. Lily mottle virus is the prevalent virus in lily crops in Brazil, in single and mixed infections with LSV or Cucumber mosaic virus (CMV).

Index terms: Lilium, Lily mottle virus, Lily symptomless virus, phylogeny, recombination analysis, RT-PCR.

\section{Ocorrência e análise molecular de vírus quarentenário em áreas de cultivo de lírios no Brasil}

Resumo - O objetivo deste trabalho foi descrever a ocorrência do Tulip breaking virus (TBV, sinonímia Lily mottle virus - LMoV) quarentenário e do Lily symptomless virus (LSV) e suas análises moleculares, para fornecer dados para a remoção do TBV da lista brasileira de pragas quarentenárias A1, pois este vírus está disseminado pelos principais cultivos comerciais de lírio no Brasil. A ocorrência desses vírus foi detectada em 12 regiões produtoras, por meio da reação de transcrição reversa multiplex (RT-PCR), com uso de iniciadores específicos para os genes das respectivas capas proteicas (CP). Foram sequenciados oito fragmentos de 800 nucleotídeos (nt), obtidos de lírios infectados com LMoV, e nove fragmentos de $600 \mathrm{nt}$, obtidos de lírios infectados com LSV. A reconstrução da árvore filogenética mostrou um ramo robusto que continha as sequências brasileiras de LMoV, outros isolados de LMoV, TBV e Tulip band breaking virus, o que indica que todos são isolados de LMoV, embora agrupados em dois subgrupos. A análise filogenética também mostrou um ramo robusto que suporta todas as sequências brasileiras e outras de LSV, com exceção de um isolado japonês de LSV. Análises de recombinação também mostraram um isolado recombinante de $\mathrm{LMoV}$, enquanto nenhum evento de recombinação foi detectado em LSV. Lily mottle virus é prevalente em cultivos de lírios no Brasil, em infecções simples e mistas com LSV ou Cucumber mosaic virus (CMV).

Termos para indexação: Lilium, Lily mottle virus, Lily symptomless virus, filogenia, análise de recombinação, RT-PCR.

\section{Introduction}

The genus Lilium L. from the family Liliaceae comprises over 80 species in seven sections (Tuyl \& Arens, 2011). Nowadays, hundreds of cultivated commercial hybrids used in horticulture as cut flowers can be classified into seven main groups: Asiatic, Longiflorum, Oriental, Longiflorum x Asiatic hybrids (LA), Longiflorum x Oriental hybrids (LO), Oriental x 
Asiatic hybrids (OA), and Oriental hybrids x Trumpet species (OT) (Tuyl \& Arens, 2011). In some regions of Brazil, a lily known as 'São José' has trumpet-shaped flowers in white color and may be a wild Longiflorum.

In Brazil, lily bulbs are imported from The Netherlands, for each cultivation cycle, to be commercialized as cut flowers and potted plants. The cultivation occurs in seven different municipalities of the states of São Paulo and Minas Gerais, the only Brazilian states to commercially cultivate lilies. In lily-producing countries, the main pathogens that infect the crop are viruses (Sharma et al., 2005). More than 20 virus species have been reported as infecting lilies worldwide, however Cucumber mosaic virus (CMV, Cucumovirus, Bromoviridae), Lily mottle virus (LMoV, Potyvirus, Potyviridae), and Lily symptomless virus (LSV, Carlavirus, Betaflexiviridae), in single or mixed infections, are the most important pathogens which cause important economic losses (Nesi et al., 2011).

In a joint action of the Brazilian Ministry of Agriculture, Livestock, and Food Supply (Ministério da Agricultura, Pecuária e Abastecimento - Mapa) and lily growers, the pathogens LSV and LMoV have been detected in commercial fields in São Paulo and Minas Gerais states (Rivas, 2010; Rivas et al., 2011); however, there is no data on the economic impact of these viruses on the lily production in Brazil, despite the removal of symptomatic plants by producers. Based on these results, LSV has been excluded from the A1 quarantine pest list (Instrução Normativa $n .{ }^{\circ}$ 59, 18/12/2013); nevertheless, TBV (Tulip breaking virus-lily strain), which is considered a strain of $\mathrm{LMoV}$ (Yamaji et al., 2001), remains an A1 quarantine pest, according to current Brazilian legal regulations.

Most studies on CMV, LMoV, and LSV in lilies addressed their global spread (Zheng et al., 2003; Sharma et al., 2005; Nesi et al., 2011; Chinestra et al., 2010), detection (Niimi et al., 2003; Nesi et al., 2011), and phylogeny (Yamaji et al., 2001; Masuta et al., 2002; Singh et al., 2008). Few reports on recombinations among LSV isolates (Singh et al., 2008) and taxonomic definitions concerning LMoV or TBV in lilies (Derks et al., 1994; Yamaji et al., 2001) are available in the literature, but no recombination event has been described for this virus.

The objective of this work was to describe the occurrence of quarantine Tulip breaking virus and Lily symptomless virus, and respective molecular analyses to provide data for supporting TBV removal from the Brazilian A1 quarantine pest list, since this virus has spread among main commercial lily crops in Brazil.

\section{Materials and Methods}

Fifty-two samples of leaves and flowers from symptomatic lilies were collected in 12 cultivation areas from seven counties of the states of São Paulo (Cotia, Holambra, and Santo Antonio da Posse) and Minas Gerais (Andradas, Araxá, Formiga, and Munhoz), Brazil. The symptoms include chlorotic spots, mosaic, blistering, vein clearing, light-yellow streaking, leaf deformation, or twisted or curled leaves plants.

Double-antibody sandwich enzyme-linked immunosorbent assay (DAS-Elisa) was performed to detect LSV and LMoV from sampled lilies and inoculated host plants, according to the protocol of BQ Support, [Bulb Quality Support B.V. (BQ Support), Lisse, The Netherlands]. Plate trapped antigen-Elisa (PTA-Elisa) was carried out, according to Silva et al. (2015), using antiserum to CMV, produced by Instituto Biológico (São Paulo, SP, Brazil), and diluted at 1/4000. The results were considered positive when absorbance values at $405 \mathrm{~nm}$ were greater than 2.5 times the mean of healthy controls.

Total RNA was extracted from leaves with TRIzol reagent (Life Technologies, Inc., Carlsbad, California, USA) according to the manufacturer's instructions. Based on Elisa tests, four leaf sets were used: asymptomatic leaves, with negative results; symptomatic leaves, positive results to LSV; symptomatic leaves, and positive to $\mathrm{LMoV}$; and symptomatic leaves, positive for both viruses.

Specific primers were designed for the respective LSV and LMoV coat-protein (CP)-encoding genes, focusing on the development of a multiplex RT-PCR. LSV and LMoV genomic sequences available in GenBank were separately aligned with the Jellyfish Program v. 3.3.1 (Field Scientific, 2008). Primers were designed using the software PRIMER3 (Rozen \& Skaletsky, 2000) and comprised a common region among isolates of the respective virus species: LMo8F 5'-AATGAGACACTCAATACTGGAGCTT-3' and LMo8R 5'-TTTATTGACATCATCTGCTGTATGC-3'; LS6R 5'-GTTAGTCACGTAGTCGAAGGTGTC-3' and LS6F 5'-GATGAGCCCACCAATTACAATAATA-3'. 
The performance of each primer pair was separately tested and optimized in a multiplex two-step RT-PCR.

First-strand cDNA was synthesized, using at least $2 \mu \mathrm{g}$ of total RNA from LSV and LMoV in a $20 \mu \mathrm{L}$ reaction mixture containing $0.5 \mu \mathrm{mol} \mathrm{\textrm {L } ^ { - 1 }}$ reverse primer, and $160 \mathrm{U}$ of GoScript reverse transcriptase (Promega Corporation, Madison, Wiscosin, USA), according to the manufacturer's instructions. PCR amplifications were performed with GoTaq Green Master Mix (Promega Corporation, Madison, Wiscosin, USA), using $3 \mu \mathrm{L}$ of cDNA, and $0.4 \mu \mathrm{mol} \mathrm{L}^{-1}$ of forward and reverse primers in a $25 \mu \mathrm{L}$ reaction mix. Amplifications were carried out under the following conditions: initial denaturation at $95^{\circ} \mathrm{C}$ for $2 \mathrm{~min}$, followed by 30 cycles of $95^{\circ} \mathrm{C}$ for $30 \mathrm{~s}, 58^{\circ} \mathrm{C}$ for $50 \mathrm{~s}$, and $73^{\circ} \mathrm{C}$ for $3 \mathrm{~min}$, and a final elongation step at $73^{\circ} \mathrm{C}$ for $5 \mathrm{~min}$. Amplicons were analyzed by $1.5 \%$ agarose gel electrophoresis. The multiplex RT-PCR amplification conditions and amplicon analyses were the same as those described above. To evaluate primer performance in the multiplex PCR using either LSV or LMoV cDNA, or both as templates, $25 \mu \mathrm{L}$ final reaction mix containing $3 \mu \mathrm{L}$ cDNA, $0.4 \mu \mathrm{mol} \mathrm{L}^{-1}$ of each of the four primers, $12.5 \mu \mathrm{L}$ GoTaq Green Master Mix (Promega Corporation, Madison, Wiscosin, USA), and $5.5 \mu \mathrm{L}$ in nuclease-free $\mathrm{H}_{2} \mathrm{O}$ was prepared and subjected to amplification as described above.

Amplicons were purified with PerfectPrep Gel Cleanup Kit (Eppendorf Scientific Inc., Westbury, New York, USA) and directly sequenced in both senses using BigDye Terminator v3.1 Cycle Sequencing Kit (Life Technologies, Inc., Carlsbad, California, USA) in an ABI 3500 DNA Sequencer (Applied Biosystem, Foster City, California, USA). Seventeen partial CP sequences -8 from LMoV and 9 from LSV - were aligned with the respective homologous sequences available at GenBank using ClustalW v.1.81. The partial CP-encoding $\mathrm{nt}$ sequences generated in this work were subjected to BLAST, in order to select homologous sequences of LMoV from Asia, Europe, and Oceania, TBV, Tulip band-breaking virus (TBBV), and Rembrandt tulip breaking virus (ReTBV), and also LSV from Asia and Europe for the analyses. Pairwise analyses were performed using PAUP* version 4.0b10 software package (Swofford, 2002). Maximum-likelihood phylogenetic trees were generated by Mega 6 software (Tamura et al., 2013), with 1,000 bootstrap replicates, using $\mathrm{TN} 93+\mathrm{G}$
(Tamura-Nei plus gamma) for $\mathrm{LMoV}$ and $\mathrm{K} 2+\mathrm{G}$ (Kimura 2-parameter) for LSV as substitution models, according to the lowest Bayesian information criterion (BIC) score.

The presence of potential intraspecific recombination events among the isolates of LMoV and LSV, the identification of putative parental sequences, and localization of the recombination break-points were investigated through their respective pairwise sequence alignments, using individual algorithms of the RDP3 package (Martin et al., 2010), with automated default settings for the RDP, GENECONV, Bootscan, MaxChi, Chimaera, SiScan, and 3Seq methods. The highest Bonferroni corrected p-value cut-off of 0.01 was applied throughout. Only recombination signals detected by at least four methods were considered to be reliable.

Symptomatic leaves were ground in $0.05 \mathrm{~mol} \mathrm{~L}^{-1}$ sodium-potassium phosphate buffer, $\mathrm{pH} 7.4$ containing $0.8 \% \mathrm{NaCl}$, and $0.02 \% \mathrm{KCl}$, or in $0.01 \mathrm{~mol} \mathrm{~L}^{-1}$ sodium-potassium phosphate buffer, $\mathrm{pH}$ 7.0, and $0.5 \% \mathrm{Na}_{2} \mathrm{SO}_{3}$. Inocula were rubbed onto leaves of five plants of each herbaceous species from Amaranthaceae (Gomphrena globosa L., Chenopodium murale L., C. quinoa Willd., and Chenopodium amaranticolor H. J. Coste \& A. Reyn.), and Solanaceae (Nicotiana benthamiana Domin, N. clevelandii A. Gray, N. debneyi Domin, N. glutinosa L., N. megalosiphon Van Heurck \& Müll. Arg., N. rustica L., and N. tabacum L. 'White Burley', 'Samsun', and 'Samsun NN'), after dusting with Carborundum (400 mesh). The infected plants were maintained in a greenhouse for at least one month after inoculation for the following of disease and symptom development.

\section{Results and Discussion}

Eleven out of the 52 collected samples tested positive exclusively for LSV, 22 for $\mathrm{LMoV}$, two for CMV, and 10 were co-infected with LSV and LMoV, or even with CMV. All symptomatic plants tested positive for at least a virus, while asymptomatic plants were positive or negative for LSV or LMoV. In general, plants with mixed infections tended to develop more severe symptoms. In addition to the leaves, it was also detected viruses in petals of the cultivar 'Yellow Blaze' (infected with LSV) and Longiflorum (infected with LMoV).

Pesq. agropec. bras., Brasília, v.51, n.5, p.615-622, maio 2016 DOI: $10.1590 / \mathrm{S} 0100-204 X 2016000500023$ 
The presence of mixed infections involving LSV and $\mathrm{LMoV}$ was a common feature among the samples collected in these regions, even in different lily varieties. The results show that LSV single infections were less frequent $(21 \%)$ than mixed infections with LMoV and CMV. The simultaneous infection by these viruses in lilies was also reported in Argentina, India, and Japan (Niimi et al., 2003; Sharma et al., 2005; Chinestra et al., 2010).

Considering that both viruses in single and mixed infections were detected in lily plants showing the same symptoms, no correlation could be found, while Singh et al. (2008) observed in LSV-infected lily a wide variety of symptoms that are dependent on the cultivar and environmental conditions.

Serological results evidenced LMoV, LSV, and CMV infections in 'São José lily', exhibiting severe mosaic on leaves. Viruses induced necrotic local lesions in chenopodiaceous, and systemic mosaic in $N$. benthamiana, N. debneyi, N. rustica and N. tabacum 'Samsun NN'. Serological tests showed that the transmitted virus on the experimental hosts was CMV only.

Some LMoV isolates can be mechanically transmitted to nonliliaceous experimental hosts (Dekker et al., 1993; Derks et al., 1994; Lisa et al., 2002), whereas others cannot (Sharma et al., 2005). However, LSV is mechanically transmitted only to lilies and alstroemeria (Derks et al., 2002). Only CMV could be transmitted from lily to experimental hosts through mechanical inoculation, which was confirmed by Elisa and RT-PCR. Because CMV infects lily and is widespread in the commercial cultivation of this plant (Chinestra et al., 2010; Nesi et al., 2011), assays were previously carried out to detect CMV in single, dual and triple infections with LSV and LMoV in cultivated lilies. The presence of mixed infection by these viruses intensifies symptoms (Zheng et al., 2003; Sharma et al., 2005) and increases economic losses (Zheng et al., 2003); therefore, CMV should be considered when diagnosing infection on imported bulbs.

The specificity of non-degenerate primers designed were confirmed by the synthesis of amplicons of the expected molecular weight, 789 or 792 nucleotides (nt) for LMoV, $594 \mathrm{nt}$ for LSV (Figure 1), and by nt sequencing of the respective fragments. Multiplex RT-PCR allowed of simultaneous detection of different viral RNAs in a same reaction. Several studies have reported the use of RT-PCR for the specific diagnosis of LSV and LMoV (Niimi et al., 2003), or even for the detection of virus genera (Zheng et al., 2003).

The data set from pairwise analysis showed that $\mathrm{CP}$ nt identity among LMoV isolates from GenBank varied from 85.3 to $99.7 \%$, and between $\mathrm{LMoV}$ isolates and ReTBV it varied from 68.4 to $71.1 \%$. From local isolates, six out of the eight CP partial sequences, gave high nt identities ranging from $94.2 \%$ to $99.7 \%$, with $\mathrm{LMoV}$ isolates from different countries. In the maximum-likelihood tree, all these isolates remained in a branch with $92 \%$ bootstrap support (Figure $2 \mathrm{~A}$ ). Two Brazilian isolates - KJ627228, from São Paulo state, and KJ627230 from Minas Gerais state -, and two isolates from Japan - AB078007 (TBBV) and AB054886 (TBV-lily) -, shared more than 97\% nt identity. In addition, these four isolates contained an extra amino acid (threonine) in the $\mathrm{CP}$, besides sharing a common ancestor in the maximum-likelihood subtree with $88 \%$ bootstrap support. The features of the Longiflorum 'São José' samples are notable, since they were collected in distant regions, and there was no exchange of bulbs between them. Isolate KJ627230 was collected in a small and isolated cultivation area, in the state of Minas Gerais, where the producer multiplies bulbs for his own use, and the origin of the bulbs is unknown. In contrast, KJ627228 was collected in a growing area, in the state of São Paulo, and this isolate, together with TBBV-tulip and TBV-lily, appeared to be lineages of the same virus ancestor.

The taxonomy of lily and tulip viruses has been actively discussed over the years (Dekker et al., 1993; Yamaji et al., 2001; Se \& Kanematsu, 2002; Zheng et al., 2003). Two of these viruses, TBBV and TBV have been considered synonymous with LMoV (Yamaji et al., 2001; Se \& Tanematsu, 2002). Dekker et al. (1993) identified the following five, distinct viruses from lily and tulip: TBV, TBBV, Tulip top breaking, ReTBV, and LMoV, based on phylogeny from 92 amino acids of the $\mathrm{CP}$ and serological relationships. The maximum-likelihood tree, which was reconstructed using 768 nt-long, partial CP gene (average $93 \%$ of the total CP length), showed two distinct subtrees which had $94 \%$ support, one of these, named group I, involved Japanese isolates of TBV-lily (AB054886) and TBBV, and two Brazilian isolates of $\mathrm{LMoV}$; the other subtree, named group II, included all $\mathrm{LMoV}$ isolates. Results obtained from pairwise 
alignments were higher than $89 \%$, indicating that they were within the range of potyvirus species, which is more than $76 \%$ for total CP gene (Adams et al., 2012); furthermore, phylogenetic analysis supports a robust branch containing the Brazilian samples and all other sequences, except for ReTBV, suggesting that all are $\mathrm{LMoV}$ isolates, although they clustered into two subgroups. Considered in the ICTV's Eighth Report (Berger et al., 2005) as a tentative species in the genus Potyvirus - ReTBV was not mentioned in the Ninth Report (Adams et al., 2012); it remained in a separate branch in the tree and shares a common ancestor with the LMoV lineages. In our analysis, ReTBV remained in a distinct branch from that containing LMoV.

Coat-protein partial nt sequences of LSV Brazilian isolates showed identities ranging from 96.3 to $99.7 \%$ with isolates from GenBank. In the reconstructed maximum-likelihood tree using $590 \mathrm{nt}$-long partial CP gene (68.5\% in average), most LSV isolates clustered in a unique branch supported by $95 \%$ bootstrap value and shared a common ancestor (Figure 2 B). Low

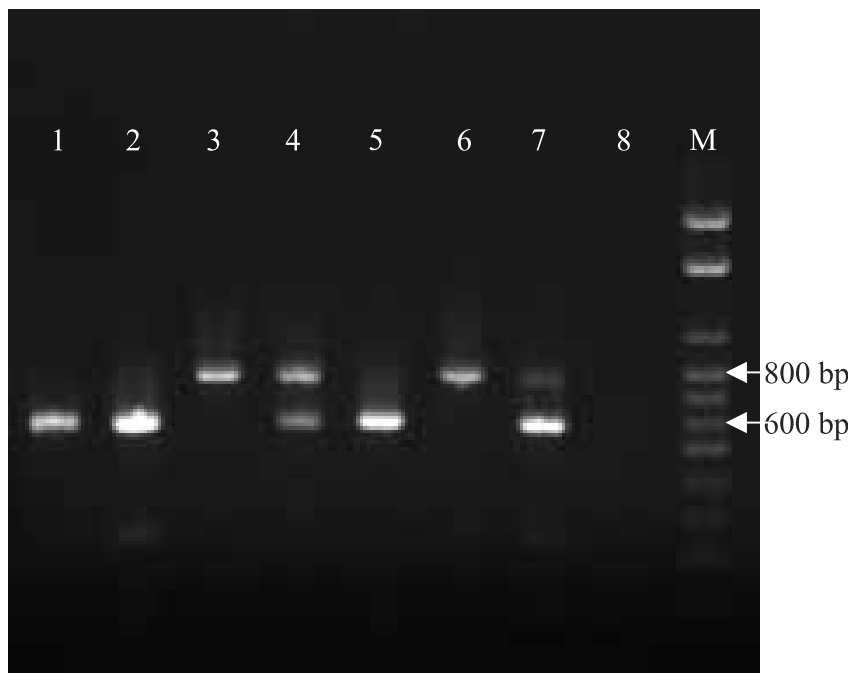

Figure 1. Amplicons from multiplex PCR for simultaneous LSV and LMoV detections analyzed in 1.5\% agarose gel: lane 1, LSV primers with sample LSV-infected; lane 2, LSV plus LMoV primers with sample LSV-infected; lane 3 , LMoV primers with sample LMoV-infected; lanes 4 and 7, LMoV plus LSV primers with mixed-infected samples; lane 5, LSV primers with mixed-infected sample; lane 6, LMoV primers with mixed-infected samples; lane 8, plus LSV primers with an asymptomatic lily sample. Arrows indicate amplicons from LMoV (800 bp) and LSV (600 bp). M: molecular marker 100 bp DNA Ladder (Norgen Biotek Corp., Thorold, Ontario, CA).

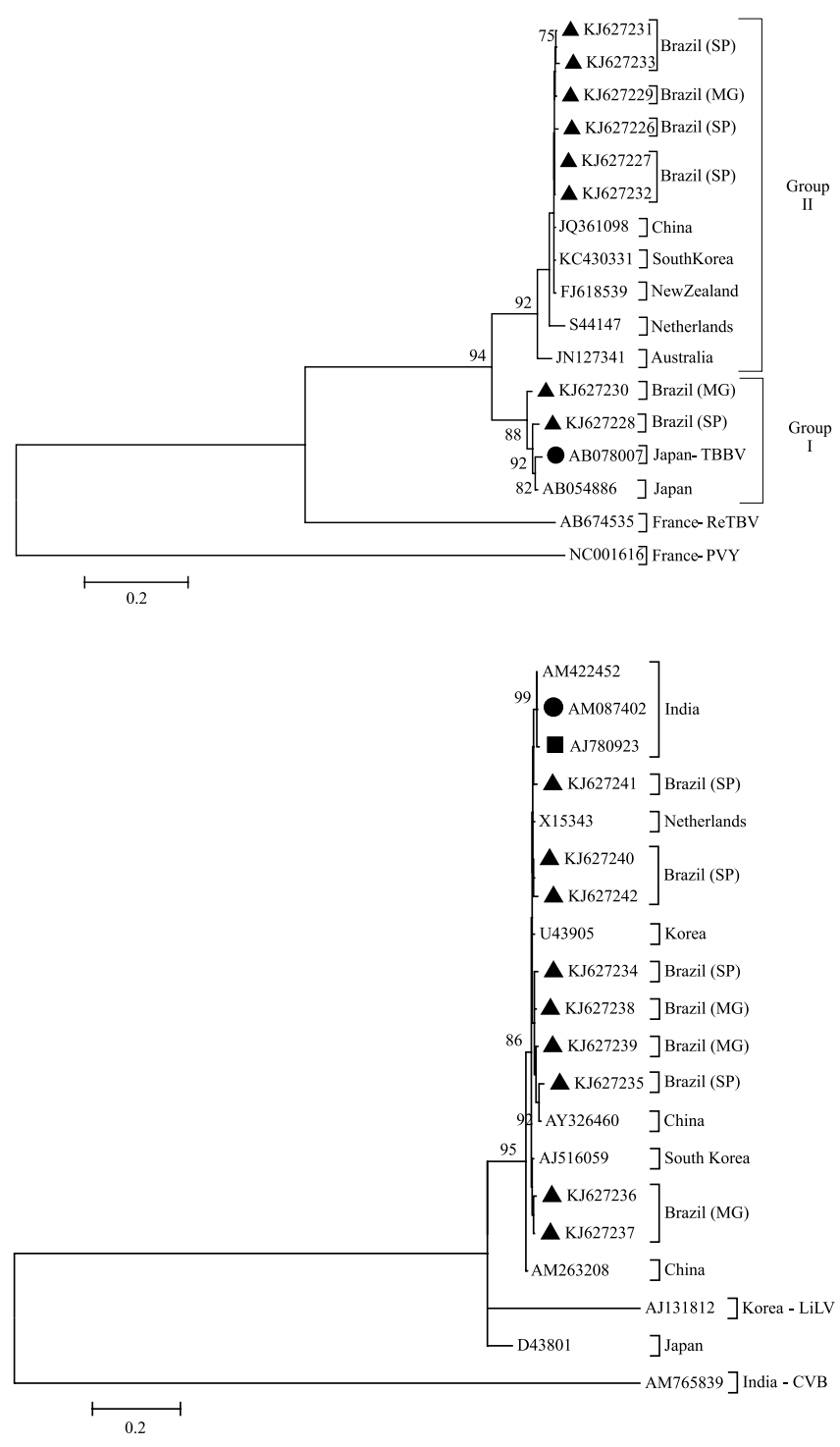

Figure 2. Maximum-likelihood trees inferred from partial coat protein sequences. Potato virus $Y$ (AF463399) and Chrysanthemum virus $B$ (AM765839) as outgroup for LMoV (a) and LSV (b), respectively. Bootstrap values are the result of 1,000 replicates and are shown in the nodes as percentages. The symbols $\bullet$ and $\boldsymbol{m}$ represent Tulipa sp. and Hymenocallis littoralis hosts, respectively. Other sequences have lilies as hosts, except for outgroups. The sequences obtained in this survey are marked by $\boldsymbol{\Lambda}$, and the GenBank accession numbers are: KJ627231 (IB2480), KJ627233 (IB2486), KJ627229 (IB2327), KJ627226 (IB0881), KJ627227 (IR1175), KJ627232 (IB2482), KJ627230 (IB2339), and KJ627228 (IS1175) for LMoV; KJ627241 (IB2476), KJ627240 (IB2469), KJ627242 (IB2513), KJ627234 (IB2712), KJ627238 (IB2329), KJ627239 (IB2339), KJ627235 (IB1175), KJ627237 (IB2327), and KJ627236 (IB2326) for LSV. 
identity scores (from 86.0 to $88.6 \%$ ) were observed between LSV Japanese isolate D43801 and other LSV isolates. The Lily latent virus (LiLV) included in the analysis showed a nt identity of $79 \%$ with D43801, and between 77 and $78 \%$ identity to other LSV isolates. Both LiLV and LSV D43801 viruses remained in distinct branches from those of LSV isolates. All LSV Brazilian isolates nested within a subtree supported by a $95 \%$ bootstrap value, and clustered LSV from different hosts (Lilium, Tulipa, and Hymenocallis) and countries, except for LSV-Japan (D43801), which showed to be a different lineage from that of the other LSV isolates. The LiLV nt identity calculated in this work corroborate those of Ryu et al. (2000) and, based on the similar nt identity of the partial CPs (from 77 to $78 \%$ ), they were similar. These authors obtained 72 or $73 \%$ from the pairwise analysis of the whole CP nt sequence, and a close phylogenetic relationship to LSV. In addition to sharing the same ancestor, both viruses display a narrow natural host range, with LSV infecting Lilium spp. (Niimi et al., 2003; Zheng et al., 2003; Chinestra et al., 2010), Tulipa sp. (Nesi et al., 2011), Alstroemeria sp. (Derks et al., 2002), and Hymenocallis littoralis (Singh et al., 2005), and LiLV infecting only Lilium lancitoium (Ryu et al., 2000).

Recombination analysis by RDP3 individual algorithms detected one potential intraspecific recombination event in the $\mathrm{LMoV}$ sequences, and one in the LSV sequences used for pairwise alignments in the present study. The first event identified in the LMoV sequences included the major part of the $\mathrm{N}$-terminus of the $\mathrm{CP}$ sequence (positions 2 to 45 in the alignment), in the isolate $\mathrm{S} 44147$, from The Netherlands. The minor parent was the isolate JQ361098, and as the putative major parent was unknown, the isolate JN127341 was used. This event was supported by four RDP3 package recombination-detection methods, RDP (average p-value $=8.000 \times 10^{-3}$ ), Chimaera (average p-value $=$ $9.223 \times 10^{-3}$ ), SiScan (average p-value $=2.379 \times 10^{-3}$ ), and 3 Seq (average $\mathrm{p}$-value $=8.279 \times 10^{-4}$ ). In addition, seven recombinants were identified in the LSV sequences used for the pairwise alignments, always containing isolate IB2326 as the minor parent, and the isolate D43801 as the major parent, with different beginning and ending breakpoints. However, the identification of the putative recombinants AY326460, U0043905, X15343, AM263208, AJ516059, KJ627235 (IB1175), KJ627240 (IB2469), KJ627241 (IB2476), and KJ627242 (IB2513), was supported only by two recombination detection methods, SiScan and 3Seq.

The high mutation rate of RNA viruses, which is partly due to high viral polymerases activity and viral turnover, together with recombination between different viral genomes, is the driving force of the evolution and variability of these viruses (Gagarinova et al., 2008; Galli \& Bukh, 2014). The recombination frequency depends on the degree of sequence identity between the viruses involved in the event, the length of viral genome and the presence of recombination hot-spots (García-Arenal et al., 2003).

Recombination events involving CP sequences have been reported for carlaviruses (Pramesh \& Baranwal, 2013), and potyviruses (Gagarinova et al., 2008). Nine putative, recombinant LSV isolates could be detected, but with a low degree of confidence. One of them was AJ516059, a South Korean isolate previously reported as recombinant (Singh et al., 2008). Even though segments of LSV CP used here were located within the region involved in the recombination event described by Singh et al. (2008), it was not possible to infer that Indian (AM422452) and Chinese (AM263208) isolates were putative parents, as described by these authors. Similarly to our results, the lack of robust recombination signals in $\mathrm{CP}$-encoding gene has also been reported for other carlaviruses. Pramesh \& Baranwal (2013) suggested that the lack of evidence for strong recombination signals in the $\mathrm{CP}$ gene in isolates of Garlic common latent virus (GarCLV) might be because the $\mathrm{CP}$ gene is a recombination cold-spot. Analysis from the entire viral genome showed that recombination appears to be more restricted into $\mathrm{CP}$ genes (Singh et al., 2012).

In the present work, only one $\mathrm{LMoV}$ recombinant out of 15 analyzed isolates was detect. Although no reports have been found of recombination for $\mathrm{LMoV}$, the obtained results provide evidence that S44147 (Netherlands) is a natural recombinant, as indicated by one potential recombination event supported by at least four RDP3 package recombination detection methods. The potential parental lineages are the isolates JQ361098 from China and JN127341 from Australia.

Galli \& Bukh (2014) describe some requirements for intraspecific recombination between isolates of RNA viruses in vivo, such as co-circulation, cellular co-infection, and survival - that is "generated recombinant forms have to be viable to spread in the viral population". Lily crops and their infecting 
viruses have aspects which fulfill these requirements and indirectly create a conducive environment to recombination. First, they are vegetatively propagated and marketed throughout the world; this fact allows of a viral isolate to be multiplied on a large scale and to coinfect with other local isolate present in the crop, which is also facilitated by the efficient transmission by aphid vectors.

Lily bulbs cultivated in Brazil came from The Netherlands. The infected starting material for bulb cultivation is largely responsible for the presence of LSV and LMoV in lily crop, even more than transmission by aphid vectors, since bulbs are usually pre-treated with insecticides before cultivation in the field or in pots. Furthermore, the presence of symptomatic plants was sporadic; in our trials, only a single plant was attacked by aphids, which was believed to be an escape of insecticide treatment.

Putative LSV and LMoV recombinant sequences detected in the present study are all from GenBank. The absence of recombinants among isolates of these viruses collected in Brazil is possible because bulbs are always imported each crop season from the same exporters, which might limit the diversity of viral isolates in the field. Additionally, as these viruses have a very restricted host range, and the possibility that native plants constitute sources of inocula is low, the chance of local recombination is reduced. To our knowledge, this is the first report of evidence of intraspecific recombination in $\mathrm{LMoV}$.

\section{Conclusions}

1. Lily mottle virus (LMoV) or formally Tulip breaking virus (TBV) is the prevalent virus in lily crops in Brazil, in single and mixed infections with Lily symptomless virus (LSV) or Cucumber mosaic virus (CMV).

2. Multiplex reverse transcription polymerase chain reaction (RT-PCR) with non-degenerate primers allows of simultaneous detection of LMoV and LSV, and can be employed for indexing in lily crops.

\section{Acknowledgements}

To Conselho Nacional de Desenvolvimento Científico e Tecnológico (CNPq) and to Ministério da Agricultura, Pecuária e Abastecimento (Mapa, process number 578356/2008-2), for financial support.

\section{References}

ADAMS, M.J.; ZERBINI, F.M.; FRENCH, R.; RABENSTEIN, F.; STENGER, D.C.; VALKONEN, J.P.T. Family Potyviridae. In: KING, A.M.Q.; ADAMS, M.J.; CARSTENS, E.B.; LEFKOWITZ, E. (Ed.). Virus taxonomy: ninth report of the International Committee on Taxonomy of Viruses. San Diego: Elsevier, 2012. p.1069-1089.

BERGER, P.H.; ADAMS, M.J.; BARNETT, O.W.; BRUNT, A.A.; HAMMOND, J.; HILL, J.H.; JORDAN, R.L.; KASHIWAZAKI, S.; RYBICKI, E.; SPENCE, N.; STENGER, D.C.; OHKI, S.T.; UYEDA, I.; VAN ZAAYEN, A.; VALKONEN, J.; VETTEN, H.J. Family Potyviridae. In: FAUQUET, C.M.; MAYO, M.A.; MANILOFF, J.; DESSELBERGER, U.; BALL, L.A. (Ed.). Virus taxonomy: eighth report of the International Committee on Taxonomy of Viruses. San Diego: Elsevier, 2005. p.819-841.

CHINESTRA, S.C.; FACCHINETTI, C.; CURVETTO, N.R.; MARINANGELI, P.A. Detection and frequency of lily viruses in Argentina. Plant Disease, v.94, p.1188-1194, 2010. DOI: 10.1094/ PDIS-07-09-0419.

DEKKER, E.L.; DERKS, A.F.L.M.; ASJES, C.J.; LEMMERS, M.E.C.; BOL, J.F.; LANGEVELD, S.A. Characterization of potyviruses from tulip and lily which cause flower-breaking. Journal of General Virology, v.74, p.881-887, 1993. DOI: 10.1099/0022-1317-74-5-881.

DERKS, A.F.L.M.; LEMMERS, M.E.C.; KONICHEVA, V.; LANGEVELD, S.A. Lily symptomless virus in Alstroemeria: identification and transmission to lily. Acta Horticulturae, v.568, p.247-252, 2002. DOI: 10.17660/actahortic.2002.568.36.

DERKS, A.F.L.M.; LEMMERS, M.E.C.; VAN GEMEN, B.A. Lily mottle virus in lilies: characterization, strains and its differentiation from Tulip breaking virus in tulips. Acta Horticulturae, v.377, p.281-288, 1994. DOI: 10.17660/actahortic.1994.377.30.

FIELD SCIENTIFIC. Jellyfish software. 2008. Available at: $<$ http://www.jellyfishsoftware.com/index.htm>. Accessed on: 29 set. 2015.

GAGARINOVA, A.G.; BABU, M.; STRÖMVIK, M.V.; WANG, A. Recombination analysis of Soybean mosaic virus sequences reveals evidence of RNA recombination between distinct pathotypes. Virological Journal, v.5, article number 143, 2008. DOI: $10.1186 / 1743-422 X-5-143$.

GALLI, A.; BUKH, J. Comparative analysis of the molecular mechanisms of recombination in hepatitis $\mathrm{C}$ virus. Trends in Microbiology, v.22, p.354-364, 2014. DOI: 10.1016/j. tim.2014.02.005.

GARCÍA-ARENAL,F.; FRAILE,A.;MALPICA, J.M.Variationand evolution of plant virus populations. International Microbiology, v.6, p.225-232, 2003. DOI: 10.1007/s10123-003-0142-z.

LISA, V.; VETTEN, H.J.; LESEMANN, D.-E.; GOTTA, P. Occurrence of Lily mottle virus in escarole. Plant Disease, v.86, p.329, 2002. DOI: 10.1094/PDIS.2002.86.3.329A.

MARTIN, D.P.; LEMEY, P.; LOTT, M.; MOULTON, V.; POSADA, D.; LEFEUVRE, P. RDP3: a flexible and fast computer program 
for analyzing recombination. Bioinformatics, v.26, p.2462-2463, 2010. DOI: $10.1093 /$ bioinformatics/btq467.

MASUTA, C.; SESHIMO, Y.; MUKOHARA, M.; JUNG, H.J.; UEDA, S.; RYU, K.H.; CHOI, J.K. Evolutionary characterization of two lily isolates of Cucumber mosaic virus isolated from Japan and Korea. Journal of General Plant Pathology, v.68, p.163-168, 2002. DOI: 10.1007/PL00013070.

NESI, B.; LAZZERESCHI, S.; PECCHIOLI, S.; GRASSOTTI, A.; RIZZO, D.; STEFANI, L.; PAOLI, M. Biotechnological approaches for identification of the main viruses in Lilium. Acta Horticulturae, v.900, p.339-345, 2011. DOI: 10.17660/ actahortic.2011.900.43.

NIIMI, Y.; HAN, D.-S.; MORI, S.; KOBAYASHI, H. Detection of cucumber mosaic virus, lily symptomless virus and lily mottle virus in Lilium species by RT-PCR technique. Scientia Horticulturae, v.97, p.57-63, 2003. DOI: 10.1016/S0304-4238(02)00125-5.

PRAMESH, D.; BARANWAL, V.K. Molecular characterization of coat protein gene of Garlic common latent virus isolates from India: an evidence for distinct phylogeny and recombination. Virus Genes, v.47, p.189-193, 2013. DOI: 10.1007/s11262-013-0909-z.

RIVAS, E.B. Lily symptomless virus no Brasil. São Paulo: Instituto Biológico, 2010. 5p. Disponível em: <http://www.biologico. sp.gov.br/docs/dt/lily_virus.pdf $>$. Acesso em: 8 maio 2014.

RIVAS, E.B.; BÔDI, E.C.A.; VAZ LOBO, R.S. Lily mottle virus no Brasil. São Paulo: Instituto Biológico, 2011. 9p. (Instituto Biológico. Documento técnico, 10). Disponível em: $<$ http://www. biologico.sp.gov.br/docs/dt/lily mottle_virus.pdf $>$. Access on: 8 may 2014.

ROZEN, S.; SKALETSKY, H. Primer3 on the WWW for general users and for biologist programmers. Methods in Molecular Biology, v.132, p.365-386, 2000. DOI: 10.1385/1-59259-192-2:365.

RYU, J.H.; PARK, H.W.; PARK, W.M.; LEE, S.Y.; RYU, K.H. Molecular analysis of the 3'-terminal region of lily latent Carlavirus from Lilium lancitoium. Plant Pathology Journal, v.16, p.231-235, 2000.

SE, T.; KANEMATSU, S. First report of tulip band breaking virus in mosaic diseased tulip in Japan. Plant Disease, v.86, p.1405, 2002. DOI: 10.1094/PDIS.2002.86.12.1405A.

SHARMA, A.; MAHINGHARA, B.K.; SINGH, A.K.; KULSHRESTHA, S.; RAIKHY, G.; SINGH, L.; VERMA, N.;
HALLAN, V.; RAM, R.; ZAIDI, A.A. Identification, detection and frequency of lily viruses in Northern India. Scientia Horticulturae, v.106, p.213-227, 2005. DOI: 10.1016/j.scienta.2005.03.011.

SILVA, M.F. da; GONÇALVES, M.C.; PINTO, L.R.; PERECIN, D.; XAVIER, M.A.; LANDELL, M.G.A. Evaluation of Brazilian sugarcane genotypes for resistance to Sugarcane mosaic virus under greenhouse and field conditions. Crop Protection, v.70, p.15-20, 2015. DOI: 10.1016/j.cropro.2015.01.002.

SINGH, L.; HALLAN, V.; MARTIN, D.P.; RAM, R.; ZAIDI, A.A. Genomic sequence analysis of four new Chrysanthemum virus $B$ isolates: evidence of RNA recombination. Archives of Virology, v.157, p.531-537, 2012. DOI: 10.1007/s00705-011-1190-x.

SINGH, A.K.; HALLAN, V.; VERMA, N.; ZAIDI, A.A. Natural occurrence of Lily symptomless virus on spider lily. Plant Pathology, v.54, p.255, 2005. DOI: 10.1111/j.1365-3059.2005.01 122.x.

SINGH, A.K.; MAHINGHARA, B.K.; HALLAN, V.; RAM, R.; ZAIDI, A.A. Recombination and phylogeographical analysis of Lily symptomless virus. Virus Genes, v.36, p.421-427, 2008. DOI: 10.1007/s11262-008-0197-1.

SWOFFORD, D.L. PAUP*: phylogenetic analysis using parsimony (and related methods). Version 4.0 beta. Massachusetts: Sinauer Associates, 2002.

TAMURA, K.; STECHER, G.; PETERSON, D.; FILIPSKI, A.; KUMAR, S. MEGA6: Molecular evolutionary genetics analysis version 6.0. Molecular Biology and Evolution, v.30, p.2725-2729, 2013. DOI: $10.1093 / \mathrm{molbev} / \mathrm{mst197.}$

TUYL, J.M. van; ARENS, P. Lilium: breeding history of the modern cultivar assortment. Acta Horticulturae, v.900, p.223-230, 2011. DOI: 10.17660/actahortic.2011.900.27.

YAMAJI, Y.; LU, X.Y.; KAGIWADA, S.; OSHIMA, K.; NAMBA, S. Molecular evidence that a lily-infecting strain of Tulip breaking virus from Japan is a strain of Lily mottle virus. European Journal of Plant Pathology, v.107, p.833-837, 2001. DOI: 10.1023/A:1012243630502.

ZHENG, H.-Y.; CHEN, J.; ZHAO, M.-F.; LIN, L.; CHEN, J.-P.; ANTONIW, J.F.; ADAMS, M.J. Occurrence and sequences of Lily mottle virus and Lily symptomless virus in plants grown from imported bulbs in Zhejiang province, China. Archives of Virology, v.148, p.2419-2428, 2003. DOI: 10.1007/s00705-003-0207-5.

Received on November 30, 2014 and accepted on September 11, 2015

Pesq. agropec. bras., Brasília, v.51, n.5, p.615-622, maio 2016

DOI: $10.1590 / \mathrm{S} 0100-204 \mathrm{X} 2016000500023$ 